\title{
Dynamics of housing stock in Romania - between politics and policies
}

\author{
Daniel Vîrdol ${ }^{\mathrm{a}}$, Bogdan Suditu ${ }^{\mathrm{b} *}$, Liliana Dumitrache ${ }^{\mathrm{b}}$, \\ Daniel Gabriel Vâlceanu'
}

\author{
a National Institute of Statistics, Romania \\ bUniversity of Bucharest, Romania \\ c NIRD URBAN-INCERC, Romania
}

The dynamics of the housing stock is one of the indicators used to express the state of the economy. In post-Communist Romania, the dynamics of housing construction sector reflected the changing of the markets estate, economic and housing policies of the country. As well, new housing characteristics (type, size, location, construction materials etc.) translate a paradigm shift of housing and/or social transformations of the meanings of housing, living environments, and residential areas. In this respect, the analysis of the dynamics of the housing stock in various morphological categories, legal or living environments at different territorial scales allows assessment of economic development disparities in Romania. Constructive practices of the past 25 years have evolved and diversified. The framework of the building sector, the categories of actors involved in the production or financing of housing multiplied, housing needs of the population have changed as well. The dynamic of real estate markets was strongly influenced by the dynamics of the housing stock. A geographical approach to the dynamics of housing stock in urban and rural areas of Romania will be drawn using regionalised statistics methods, correlated with institutional context analysis. The study aims to identify and analyse the main features of the dynamics of the housing stock in Romania, being privileged perspective and spatial components analysis regionally different types of housing. Also, analysis of the dynamics of the housing stock is correlated with the dynamics of the legal, urban planning and lending. The results of this study can be used to base the futures housing policy in Romania.

Key Words: housing policies, communism and post-communism ideologies, systematization, urban renovation, public and private housing stock, living changes, resilience, Romania.

Article Info: Received: April 3, 2015; Revised: September 24, 2015; Accepted: October 25, 2015; Online: November, 2015.

\footnotetext{
* Corresponding author

Address: University of Bucharest, Faculty of Geography, 1 Nicolae Balcescu Avenue, 010041, Bucharest, Romania.

Phone: +40213153074|Email: b_suditu@yahoo.fr
} 


\section{Introduction}

The dynamics of the housing stock is one of the indicators used to express the state of an economy, but also the ideological orientation and the coherence of specific public policies (Pichler-Milanovich, 2001; Lux, 2003). In communist and post - communist Romania, the dynamics of housing construction sector and its segments (private/public ownership, rural/urban housing, individual/collective housing) was reflecting political, economic and living ideologies. The housing characteristics promoted by each period (type, size, location, construction materials etc.) translate a paradigm shift of housing and/or social transformations of the meanings of housing, living environments, and residential areas (Bengt and Tsenkova, 2004; Hegedüs, 2009; Herfert et al., 2013). In this respect, the analysis of the dynamics of the housing stock in various historical periods, in the two living environments (urban, rural) and at different territorial - administrative scales allow the identification of the mechanisms of housing production, but also the assessment of economic development disparities in Romania.

Constructive practices of the communist period, respectively post - communist, permanently have evolved and diversified (Morton, 1979; Baross and Struyk, 1993). The overall framework of the building sector, the categories of actors involved in the production or financing of housing multiplied, housing needs of the population have changed as well (Lux and Sunega, 2014). During the determined period to be examined, in each decade, the logics, the role and the importance of public and private actors, but also the production, construction or distribution rules permanently changed. Thus, although the whole dynamics of the housing is upward, territorial analysis of its various components shows that this dynamic is not uniform, with different rhythms and characteristics (Vâlceanu et al., 2015).

The study wants to identify and to examine the main characteristics of housing stock from Romania during communist and post-communist period. The geographical approach of the dynamics of housing stock in urban and rural areas of Romania aims the territorial statistical analysis, and also the explanation of differentiated dynamics of housing indicators as an effect of transformation of ideological, social - economic and institutional context.

The source of data is the housing census performed during the years 1966, 1977,1992, 2002 and 2011, but also the territorial databases regarding the dynamics of housing stock in Romania, established by the National Institute of Statistics after 1990 .

The limits of statistical analysis are imposed by the absence of data regarding housing stock for the first two communist decades. The information concerning the people and the housing census from 1948 are incomplete, but in 1956, the census was based only on people records. In this context, the statistical analyses favoured the period 1966-2011, even if the other elements cover the whole examined period. We are mentioning that the results of this study may be used for substantiating housing policies in Romania. 


\section{The block of flats - a favoured model of urban construction during communist period}

The strong urban dynamics during the communist period, even at its beginning, is connected to industrialization policy and implicitly urban planning of Romania. The industrialization process, and implicitly the development of a numerous and skilled working class, as a process carefully guided, being a first-degree objective for the communist regime, mainly having two principal reasons: on one hand, the need of a social basis, a majority, even a relative one, for regime, and on the other hand, the country modernizing program, essentially designed as a fastindustrializing process, and the transformation of Romanian society from an underdeveloped one having an agrarian character, into an industrial one (Tănase, 1998: 135). Thus, the communist state even during its first years was focused on concentrating and orienting natural, human, financial and production resources, the territorial practices and the dynamics of housing sector being relevant for the political proprieties of that period.

Following Soviet pattern regarding the society transformation, after 1948 in Romania a special attention was paid to industrialization and urban planning. This social and economic context, where the urban population increased over the accommodation possibilities in existing free housing or constructed housing, created the premises of applying the first strict rules regarding the urban housing. In this context, the people and the housing census from 1948, more than a periodical scientific approach, it was a source for identifying social and demographic structures of urban population, one of the results being the knowledge and the accurate indexing of housing that may be further mobilized during the housing nationalizing from March 1950, for providing an accommodation to representatives and supporters of new power installed in Romania.

By the Decision of the Council of Ministers no. 2447/1952 was regulated the construction and reconstruction of towns, and also organizing the activity in the field of architecture, determining that „the towns and the localities from our country inherited a difficult state from bourgeois and landowner exploiting regime ... being anarchically developed according to narrow interests of exploiting bourgeoisie and landowners ... [who] despising the valuable artistic tradition of our people and servilely adopting the trend of box hoses from capitalist West, propagated the formalism and the cosmopolitism, expressions of bourgeois ideology unfamiliar for the people", recommending that the architecture "must follow the example of soviet architecture, the architecture of socialism and of the period of communism construction... following the brilliant directives of Lenin and Stalin". The application of the provisions of this decision means radical changes in urban development policy, like imposing vertical development of the town, by the construction of high blocks of flats. Statistically, the modification of living stock structure following the construction of blocks of flats is showed by the dynamics of the indicator of housing average for each building. If in 1948 in some 
towns that became county capitals and implicitly big cities during next decades there were no blocks of flats (Vaslui, Hunedoara, Slatina, Slobozia etc.), during the communist period this was changed. Even with priority, the issue of housing was not solved during the first decades by allotment of significant amounts of money for construction of new housing, the existing economic context requesting a priority of the budget for industrial development. Because of the strong need for housing, will be proposed and realized new housing according to request and also the allotment of budget from the central level. The living model for solving this issue was the construction of blocks of flats, their architecture, structure and comfort standards being permanently modified during next decades. During the communist period, political decisions and concrete technical norms confirmed the change of living paradigm.

Inthe urban environment, was generalized the execution of collective housing buildings type blocks of flats, while limiting until disappearing (depending the size of towns) of private initiatives of pavilion housing construction. Because of the lack of sufficient funds, the incoherence of urban development programs - at the beginning mainly depending on the evolution of Soviet urban planning models or the existence of other economic priorities, in the urban environment the main actors, the State and the people, nearly had the same participation on the development of housing stock. The mechanism of producing urban space was changed, passing from plotting urban territory and realizing individual housing, specific for models of classic residential development based on the free choice and private ownership, to an urban planning with a central orientation based on construction of residential complexes of collective housing where the plot, the private initiative disappeared. The construction rules, architectural types, and also the areas where may be erected buildings were strictly determined by systematization drawing. Thus, the housing will be concentrated into blocks of flats having various heights and number of sections, constructed according to urban planning models of Stalinist type, functional, linear or in big residential complexes. In 1966 the number of housing situated in blocks of flats significantly increased, the highest values of the ratio housing per buildings being bigger in industrialized counties having a superior degree of urban planning: Bucharest $(2,43)$, Brăila (2,23 housing / block of flats), Hunedoara (2,22), Iaşi (2,08), Cluj (1,93), Timiş $(1,96)$, Galaţi $(1,92)$, Sibiu $(1,91)$, Bacău $(1,88)$ etc.

\section{New ideological approaches of individual housing}

Mainly corresponding to urban suburbs and rural environment, the pavilion housing will continue to increase rural types for a long period, but will be performed using strong and more accessible construction materials (bricks and concrete). The high percentage of rural housing and their individual character was emphasized by the housing census from 1966. The lands situated within the builtup area are inherited or purchased for constructing houses for young people 
married or for numerous families that need a bigger space. By the credits for purchasing construction materials, the vernacular housing are substituted or modernized. These territories were transformed at the end of 60 ', when many people, especially young proletarians, abandoned them for moving to apartments distributed by factories (Noica, 2003: 110). By the policies of industrialization, urban planning, for favouring the towns and isolating the villages, the social distances (including concerning the living) between villages and towns are increased! The urban area becomes an area of opportunities, and the rural one, spatially and socially a peripheral one. The housing dynamics will follow the demographic dynamics, the public investments being concentrated first of all on bug cities, and the other towns (Figures 1, 2).

In rural environment, modernizing and changing living paradigm were differently expressed, in the context of unfavourable policies of this territory. The public investments for housing construction have a demonstrative, ideological role. Only in few villages will be realized collective housing (usually, the model of a block of flats having one floor and 4 apartments) for the employees of agricultural cooperatives having an important production or for other employees of rural small industrial or mining. Also, in rural localities having tourist functions or therapeutic potential (during last decades some of them getting urban statute) or in pre-urban areas of bug cities (Bucharest, Braşov, Iaşi, Constanţa, Cluj-Napoca etc.). We are mentioning the provisions of the Decree no. 142/1952 regarding the functions of localities situated out of administrative limit of Bucharest, where "will be created an agriculture basis of intensive culture and networks of irrigation for providing a good supply of vegetables and fruits to people and that may be used for construction of collective and individual leisure houses and sanatoriums etc.". For this purpose, by Decree no. 142/1952, the localities Snagov, Ciofliceni, Ciolpani, Gruiu, Turbați and Balotești from Snagov district, Bucharest region, were declared as „worker's resorts”. In the rest of rural territories, there is a slow modernization and substitution of housing stock, in various stages: influenced by rural employees, by increasing the access to loans to rural people for purchasing construction materials, some employees of the factories from big cities who live in suburb localities, but also by policies of "urban planning of villages" initiated by the state after 1974 .

\section{Towns having administrative functions: a new image for a new state}

In the context of increased flows of migration to Bucharest and to the other 12 "localities to crowded centres (Bucharest with an area of $20 \mathrm{~km}$ around the city, Stalin town (n.n. Braşov), Ploieşti, Cluj, Oradea, Timişoara, Reşiţa, Hunedoara, Cugir, Constanţa, Galaţi and Iaşi), in the years 50' were applied limiting steps and also for structuring migration flows (cf. Annex to Decision of the Council of Ministers no. 1152/1957 regarding the application of the regime of population records, Collection of Decisions and Dispositions of the Council of Ministers no. 53 from August 5, 1957). The employees who in 1968 worked in Bucharest and in the other big cities declared as 


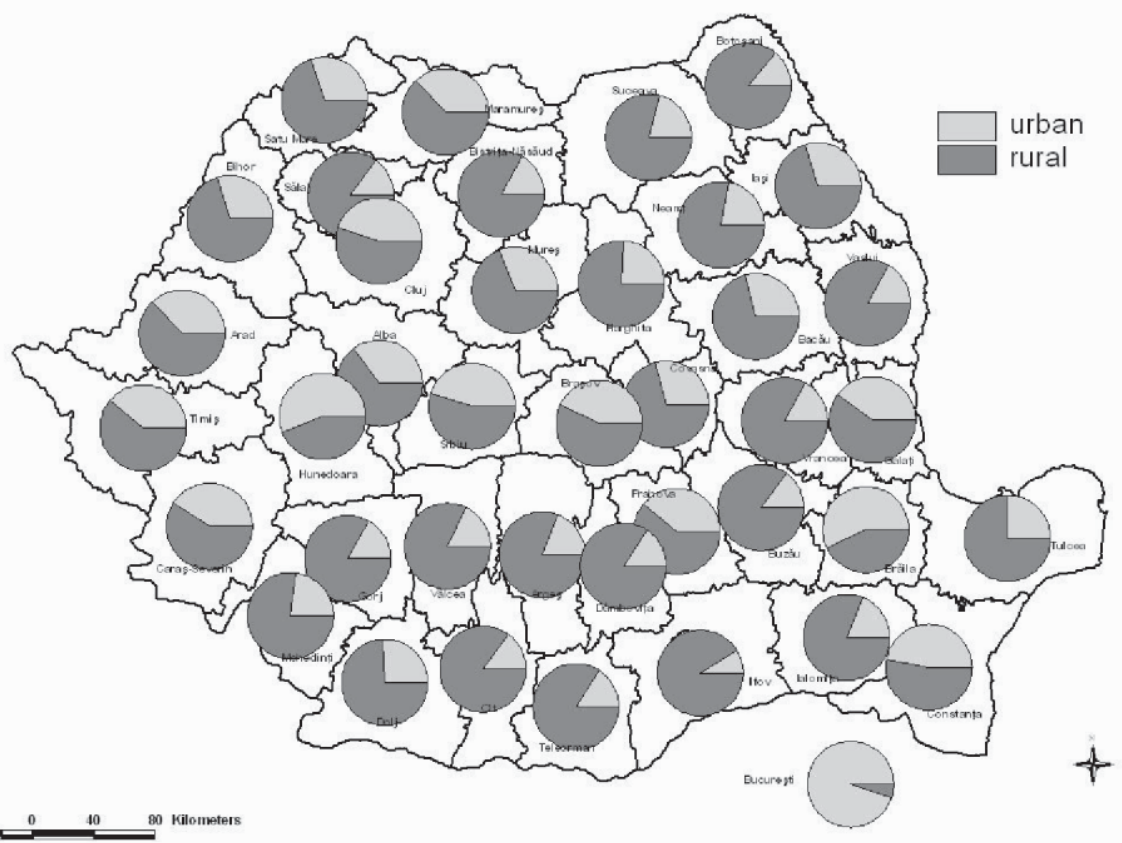

Figure 1. Share of housing situated in urban and rural environments in 1966

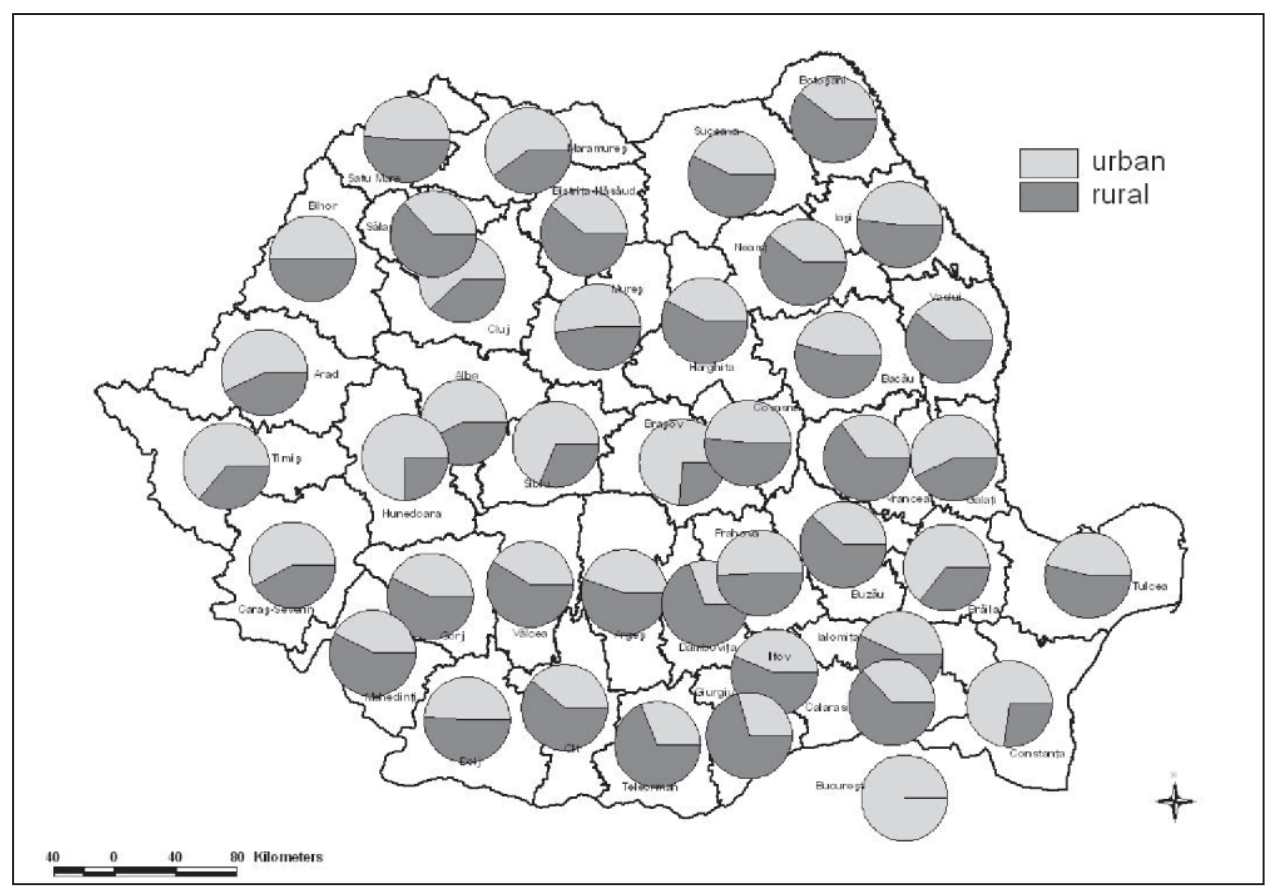

Figure 2. Share of housing situated in urban and rural environments in 2011 
"closed" for new residents (Arad, Braşov, Brăila, Bucureşti, Cluj, Constanţa, Craiova, Galaţi, Iaşi, Piteşti, Ploieşti, Sibiu, Timişoara, Târgu Mureş), but they had the domicile in the localities around them, had to be supported for constructing their own house in that residing locality, if they had no personal house. The status of "Big cities (municipalities)" was improved according to Annex 2 of the Decision of the Council of Ministers no. 1651/1968. They had the possibility of a credit of maximum LEI 15.000 for a period of 10-15 years, with no right to construct personal houses in big cities where they had the jobs or in the localities situated at a distance smaller than $40 \mathrm{~km}$ from their built-up area. This rule was improved according to Art. 8 of the Decision of the Council of Ministers no. 1735/1968 for applying the provisions of Law no. 9/1968 regarding the development of housing construction, sale of housing from state stock to population and construction of real estate for leisure or tourist.

The administrative and territorial role of some cities (capital, area, district, county residence) will determine significant orientations of public funds for developing and diversifying local economic activities, first of all, industry development, meaning a demographic increase and implicitly an increase of public investments to realize blocks of flats. We may observe the dynamics of housing stocks realized during the first two communist decades in the towns area residence (Braşov/1953-1961: Oraşul Stalin, Ploieşti, Cluj, Oradea, Timişoara, Constanţa, Galaţi and Iaşi), and also other towns having an important role for national industry (Reşiţa, Hunedoara, Oneşti/1965-1989: Gh. Gheorghiu-Dej, Victoria etc.). The last great administrative - territorial reform from Romania was in 1968: the territory was divided into counties, appeared new residences or the existing ones were privileged comparing to other towns having an advantageous economic history or natural privileges. As the administrative statute in the context of the centralized socialist economy means benefits like public investments, the new residences of the counties after 1968 became the most important and biggest cities in Romania. The political arbitral decision will determine some alterations of demographic hierarchy and in that of housing stock in these towns, favouring the new residences. From the public investments in housing, constructions had benefits also 108 localities (33,7\% from Romanian towns) declared as towns during the period 1948-1989. Getting urban statute, by a decision of the highest level, means a transformation of urban physiognomy, respectively an increase of residential districts against individual pavilion houses.

\section{Territory systematization, urban renovation and living transformations}

Also, by applying the provisions of Law no. 58/1974 regarding the territory systematization were regulated the steps for "urbanizing the villages", being defined the "reliable" villages and also those proposed for becoming towns. The systematization rules, differently transposed into drawings and practice from a place to another, represented the operational instrument the basis of "socialist reconstruction" of villages and towns by demolition and renovation. By the application of this policy, in many villages from Romania were demolished some 
parts of the central area for providing space to "modernity": a shopping centre, one or more blocks of flats, a square etc. In the peri-urban area of Bucharest, for instance, the villages suffered significant urban modifications, from the demolition of centres for providing the space to a new „civic centre”, to demolition of an important part in order to erect blocks of flats (80\% of Otopeni was demolished, Cornetu, 30 Decembrie (now called the town 1 Decembrie), Snagov, Ghermănești, Bragadiru - over 70\%, Ciolpani, Săftica, Ciofliceni) or even fully destroyed (Vlădiceasca). In the same period were demolished also the villages Buda and Ordoreanu for the lake from Cornetu, and also the village Dimieni for extending Otopeni Airport (Dumistrăcel, 1995: 86). One of the purposes of systematization was limiting spatial extension of towns and villages, imposing clear limits to each one, with no possibility to develop proximity relations and living forms at their limit. In the villages, according to systematizing law, the developing rules imposed, through systematizing, grouping the houses from small villages to those having development perspectives, in order to transform rural localities having the best development conditions into urban economic and social centres during a period of 10-15 years, the new constructions usually having two floors; for all villages, in living area was imposed a density of $1.500 \mathrm{~m}^{2}$ useful surface/ hectare.

The fever of economies at the beginning of the years 1980 also affected the sector of housing construction, being modified standards and costs of housing erected by the state. This step aimed also to create the necessary budgets for covering the need of new housing for demolished people. Therefore, by the Decree no. 216/1981 it was imposed for $60 \%$ of the planned volume of housing for the period 1981-1985 smaller surfaces and mainly being distributed in Bucharest and in big cities of Romania. The issue of living in the new context imposed an increased attention to be paid based on dimensions of rooms in the apartments, the surfaces of living rooms and annexes (pantry and lumber room), requesting to be correlated to the number of persons, limiting the halls for a fluent and short circulation to all rooms of the apartment. It was encouraged the valorisation of all areas, recommending for balcony and loggia forms and dimensions proper for giving them plastic but also a practical aim, through adequate furniture (Lăzărescu, 1982: 12).

\section{Housing stock during communist period - some statistical data}

The increase in housing number and the easier access for families to housing determined a permanent decrease of living density during examined period: from 3,21 persons/house, respectively 3,55 persons/house in the year 1966 to 2.69 persons/house, respectively 2,25 persons/house in 2011. According to these median values, there are differentiations. In the rural environment, the number of persons / house decreased from 3,32 in 1966 to 2,32 in 2011, and in urban environment decreased from 3,99 to 2,19 for the same period. The statistical analysis of living indicators shows a permanent improvement of living quality: the 
medium averages of persons/room decreased during examined period from 1,76 (2,07 in the urban environment, respectively 1,61 in the rural environment) to 0,81 ( 0,84 in the urban environment, respectively to 0,78 in the rural environment). The industrialization of housing construction, typical of the communist period, determined an obvious increase in housing number, especially those situated in collective buildings (blocks of flats). The statistical information confirmed the ascendant dynamics of the number of rooms/house from 2,02 rooms/house in 1966 to 2,46 in 1992 , respectively to 2,78 in 2011 . Obviously, according to public policies and volume of investments for the urban environment, respectively the rural one, the dynamics of indicators regarding the characteristics of housing stock territorially brings differentiations. generally, the housing becomes bigger (number of rooms and surfaces) and more comfortable (municipal infrastructure), even if in territorial profile there are some disparities (Tables 1, 2; Figure 3).

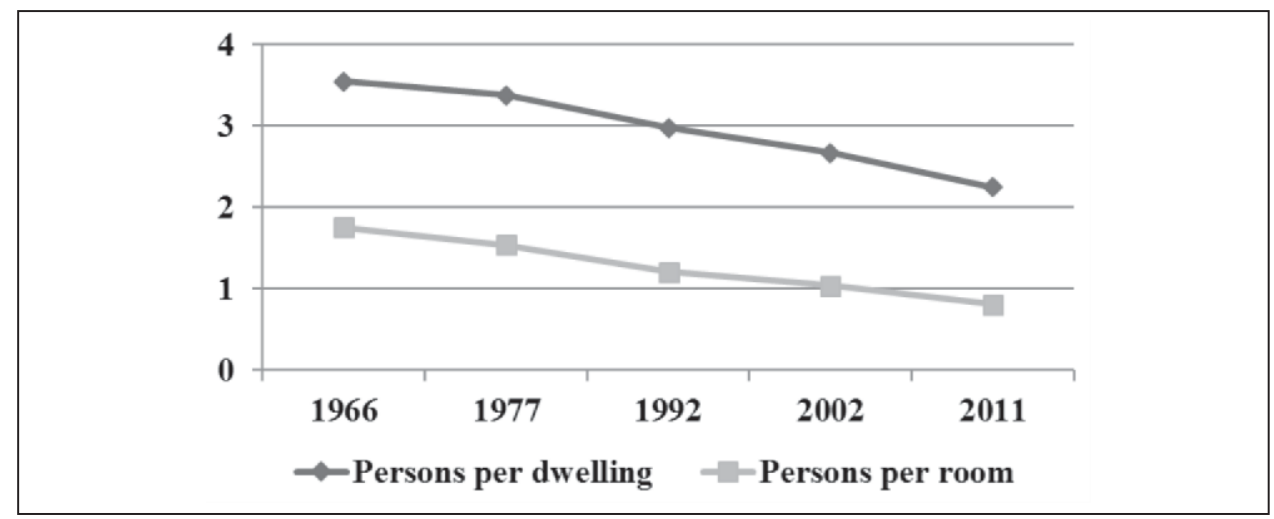

Figure 3. Dynamics of persons / housing and persons / room in Romania at the census between 1966 and 2011

Source: data processing of I.N.S., 2015

Table 1. Indicators of living at the census from the period 1966-2011

\begin{tabular}{|l|c|c|c|c|c|c|}
\hline \multirow{2}{*}{$\begin{array}{l}\text { Housing } \\
\text { Index }\end{array}$} & $\begin{array}{c}\text { Total/Residential } \\
\text { environment }\end{array}$ & \multicolumn{5}{|c|}{ Year } \\
\cline { 2 - 7 } $\begin{array}{l}\text { Persons per } \\
\text { household }\end{array}$ & total & 3,21 & 3,17 & 3,13 & 2,93 & 2,69 \\
\cline { 2 - 7 } & urban & 2,88 & 3,10 & 3,12 & 2,86 & 2,57 \\
\cline { 2 - 7 } & rural & 3,44 & 3,22 & 3,14 & 3,02 & 2,83 \\
\hline \multirow{2}{*}{$\begin{array}{l}\text { Persons per } \\
\text { dwelling }\end{array}$} & total & 3,55 & 3,38 & 2,98 & 2,67 & 2,25 \\
\cline { 2 - 7 } & urban & 3,99 & 3,46 & 3,04 & 2,68 & 2,19 \\
\cline { 2 - 7 } & rural & 3,32 & 3,32 & 2,91 & 2,66 & 2,32 \\
\hline $\begin{array}{l}\text { Persons per } \\
\text { room }\end{array}$ & total & 1,76 & 1,54 & 1,21 & 1,04 & 0,81 \\
\cline { 2 - 7 } & urban & 2,07 & 1,57 & 1,28 & 1,11 & 0,84 \\
\cline { 2 - 7 } & rural & 1,61 & 1,52 & 1,14 & 0,98 & 0,78 \\
\hline \multirow{2}{*}{$\begin{array}{l}\text { Households } \\
\text { per dwelling }\end{array}$} & total & 1,11 & 1,07 & 0,95 & 0,91 & 0,84 \\
\cline { 2 - 7 } & urban & 1,38 & 1,11 & 0,97 & 0,94 & 0,85 \\
\cline { 2 - 7 } & rural & 0,96 & 1,03 & 0,93 & 0,88 & 0,82 \\
\hline $\begin{array}{l}\text { Average } \\
\text { number of } \\
\text { rooms per } \\
\text { dwelling }\end{array}$ & total & 2,02 & 2,20 & 2,46 & 2,56 & 2,78 \\
\cline { 2 - 7 } & urban & 1,92 & 2,20 & 2,37 & 2,42 & 2,60 \\
\cline { 2 - 7 } $\begin{array}{l}\text { Average } \\
\text { area per } \\
\text { dwelling }\end{array}$ & rural & 2,06 & 2,19 & 2,55 & 2,71 & 2,98 \\
\cline { 2 - 7 } & total & 27,59 & 29,62 & 33,75 & 37,55 & 47,99 \\
\cline { 2 - 7 } & urban & 28,34 & 30,89 & 34,01 & 37,56 & 49,02 \\
\hline \multirow{2}{*}{ rural } & 27,20 & 28,67 & 33,45 & 37,54 & 46,76 \\
\hline
\end{tabular}




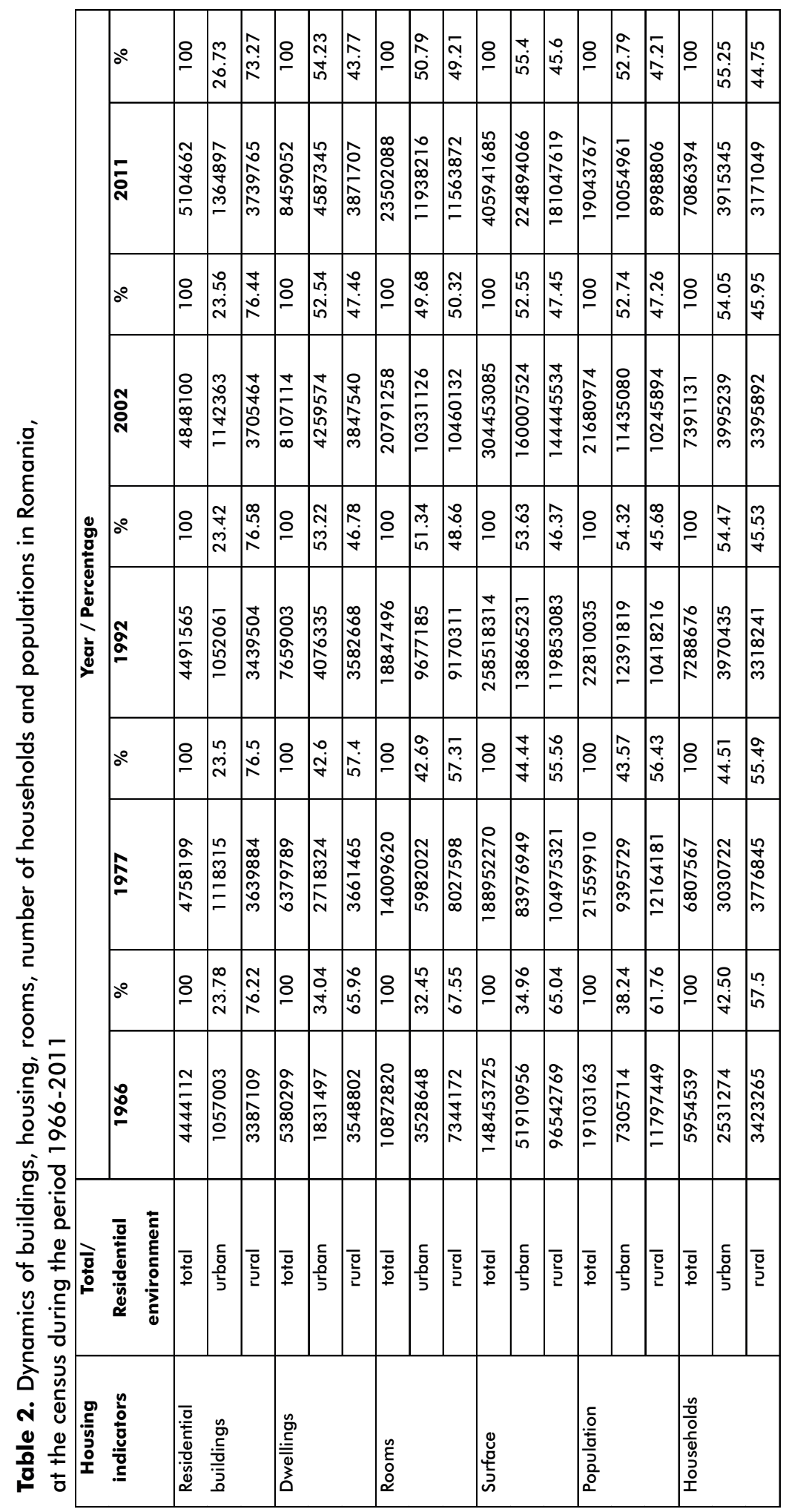




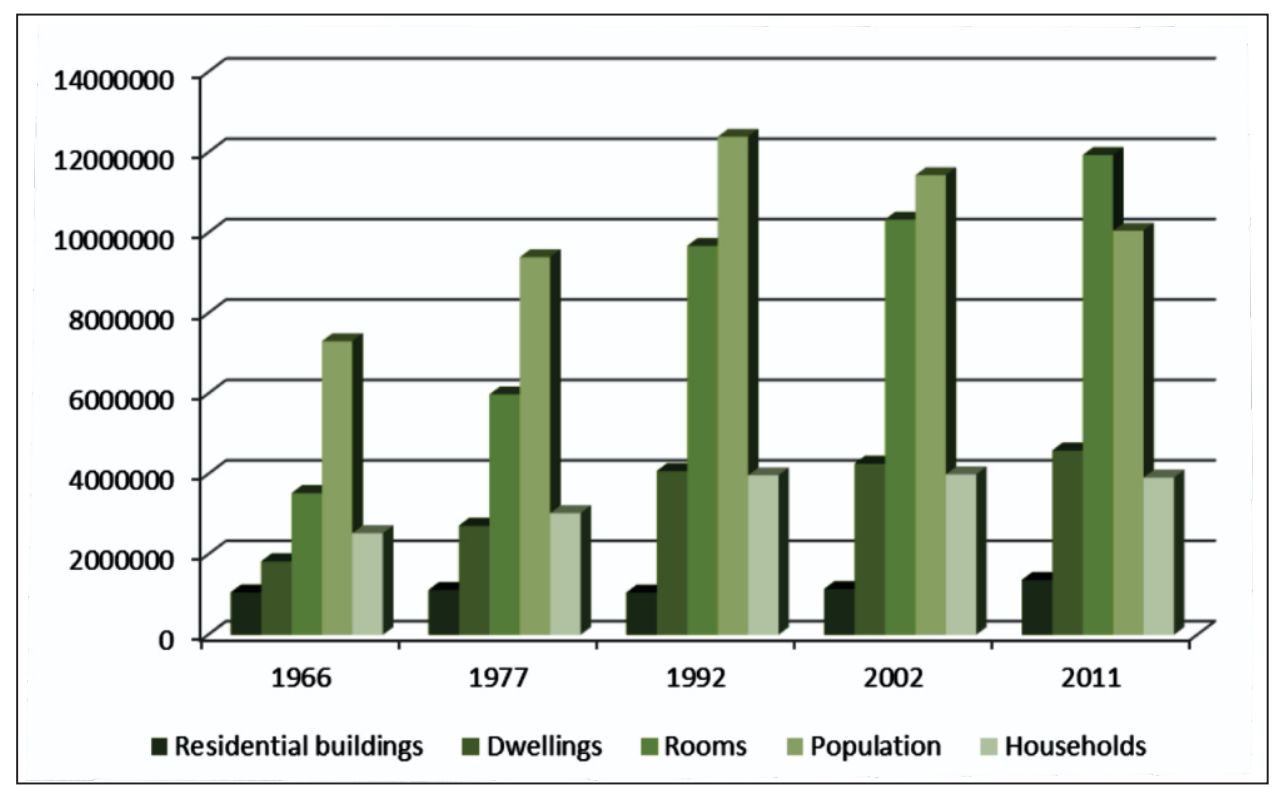

Figure 4. Dynamics of buildings, housing, rooms and households and population in Romania at the census between 1966-2011

Source: data processing of N.I.S, 2015

The pro-birth rate policy is reflected by the increase of about $19,4 \%$ of the number of population during communist period at the national level (from about 19,1 mil. inhabitants in 1966 to 22,8 mil. inhabitants in 1992), and economic changes and liberalization of international migrations decreased the total population during post - communist (19,04 mil. inhabitants in 2011). The biggest increase of population was observed during communist period in the urban environment, of $69,61 \%$, in the context of industrialization of urban localities and migration of labor force from the rural environment to urban one. Also, this step may also explain the demographic dynamics in the rural environment, the population having some increase from about 11,7 million to 12,1 millions of persons, between 1966 and 1977.

After 1977, by a migration of labor force and transformation of new localities as towns, was observed a decrease of $35,32 \%$ of the rural population until 2011. The number of households increased at the national level by about $19 \%$ during the period 1966-2011, the most notable increase being in the urban environment $(54,67 \%)$. In the rural environment, the number of households permanently decreased by about $20 \%$ after 1977 until now, a common trend in the mentioned political, economic and demographic context (Figure 4).

At the end of the communist period, the landscape of urban and rural living was significantly differentiated, even if sometimes the distance between them was small. The boundaries of localities are clear, and the towns and the villages situated in the spatial neighbourhood will be remote from the morphological and functional viewpoint. The share of apartments in blocks is significant in most of the towns, but without disposition of individual pavilion living. By their architectural characteristics, by number and location in towns (isolated between the houses in central areas, bordering the big central and pericentral avenues or grouped in 


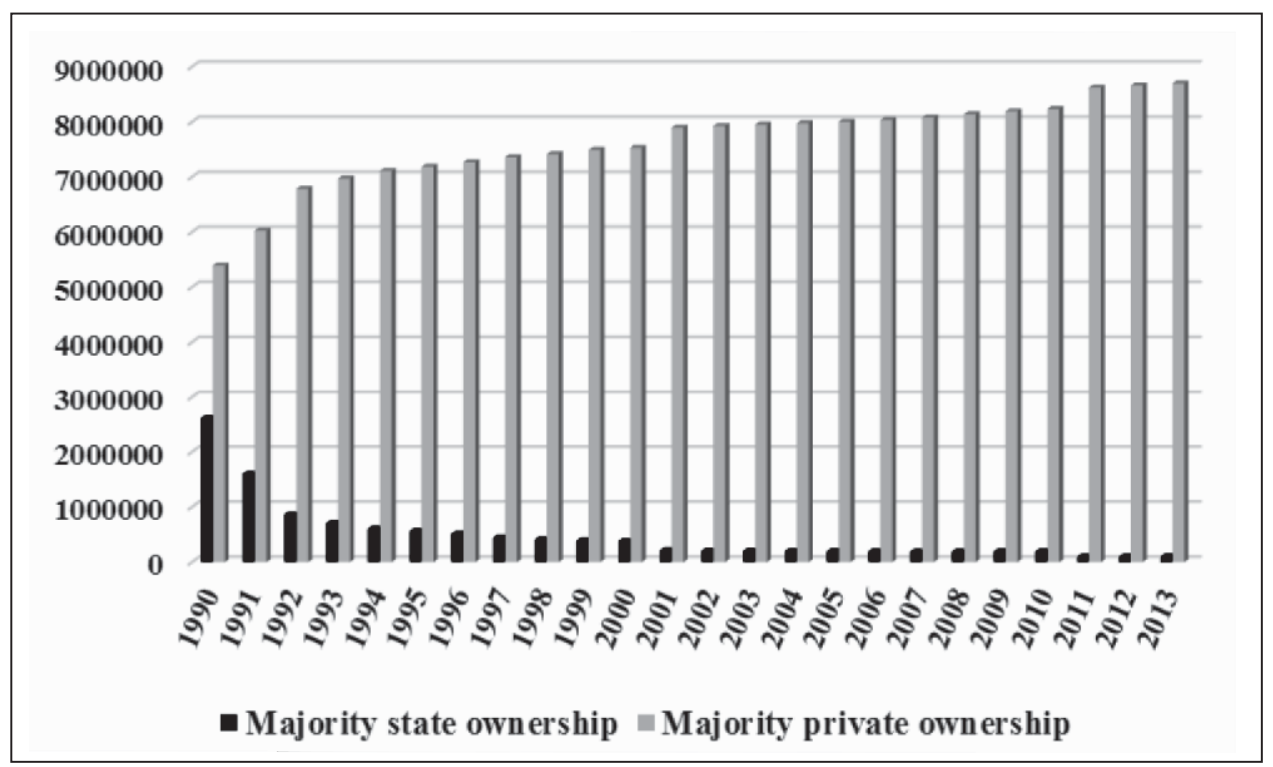

Figure 5. Existing housing at the end of the year on ownership forms in Romania, during the period 1990-2013

residential complexes of various sizes), the blocks of flats and the structure of residential areas during communist period have a significant influence on the life and the dynamics of towns also during post-communist period.

\section{Housing during post-communist: freedom of choice and resilience}

During post-communist period were modified mechanisms and principles regarding housing construction and distribution. The elimination of mobility restrictions, of those concerning the access to ownership, the freedom to erect by own forces, the freedom of choosing desired residence place, are essential elements that transformed the structures of housing stock and residential characteristics of villages and towns. The liberalization of housing and land market, the decrease in the role of the State in the housing production, the disappearance of control system and housing allotment by the State or enterprises, provoked an accentuated dynamics of free change of housing, of real estate market and implicitly, the housing construction sector by private financing (Figure 5). After 1990, the role of the state in construction and allotment of new housing was gradually decreased, becoming insignificant, the monopoly of its control on the evolution of real estate market or inventory of housing changes in the town being substituted by individual free decisions. The administrative barriers were removed, and the liberty to travel, to change or to erect means new flows and principles of territorial development. Immediately after the change of communist regime were abrogated imposed rules regarding the sole ownership (one housing and one vacation house for each family), the restriction of urban domicile and the limitation of extending the builtup area of localities and towns (Suditu, 2012: 74). 
The change of this rule provoked the development of real estate market and the modification of past practices for purchasing and adapting the housing according to the family size. After the first stage, corresponding to the years 1990-1992, when most of the tenants from the apartments constructed by state funds had the possibility the buy the respective housing inside the town, in the field of housing will be a dynamic stage of selecting and adapting housing characteristics to the needs and the aspirations of involved persons. Now the housing becomes more than a shelter, a heritage good, an investment, and by own characteristics and location a trademark of social prestige, a symbol of success (Suditu, 2009: 84).

The minimal standards regarding the housing construction were abandoned. There was erected a lot of housing and, usually, of great dimension. The state intervention is reduced, by programs of national financing or the National Agency for Housing (established in 1998) being erected during the entire post-communist period only 31.831 housing for young people, 534 office housing for physicians and 3.009 social housing, including housing for persons evacuated from nationalized houses retroceded to ex-owners (M.R.D.P.A, 2013; N.H.A., 2015).

The number of actors on the housing market is permanently increased, also as the differentiated housing request. In urban landscape and real estate market, the old individual housing and the apartments from the communist blocks of flats represent the object of the most real estate transactions. By the disappearance of dirigisme housing policies during the communist period, the urban living has a significant resilience process.

The constructive options of inhabitants are mainly oriented to individual housing. This fact determined an increase of the prices for lands and individual housing, limiting the access of many potential buyers. The accessible alternative of the middle class and acceding to real estate market becomes a housing situated in a collective building (new blocks of flats of various sizes) or a housing outside towns. After 2000, in the context of increase of real estate crediting and multiplication of investment funds oriented to housing construction, there is an explosion of real estate investments in residential complexes (including pavilion houses, but also blocks of flats), most of them situated in outskirts urban areas or peri-urban localities. We are also mentioning that the dynamics of urban housing stock according to official statistics during the period 1990-2015 was also modified by the contribution of 60 new towns declared in this period.

In the villages around big cities or accessible localities having tourist potential at the seaside, hill or mountain areas also increased the number of erected housing.

The inhabitants of these localities, retired persons from towns, the townspeople wishing the second residence, the residents of that area working abroad, investors in the sector of residential constructions, etc. erect housing. In these areas, the rural environment and the rural living are reconsidered and permanently receive a higher residential interest. Also, following the extension of public investment programs into municipal infrastructure in a rural environment, the process of housing modernizing, rehabilitating and improving by the initiative of tenant owners is increasing. 


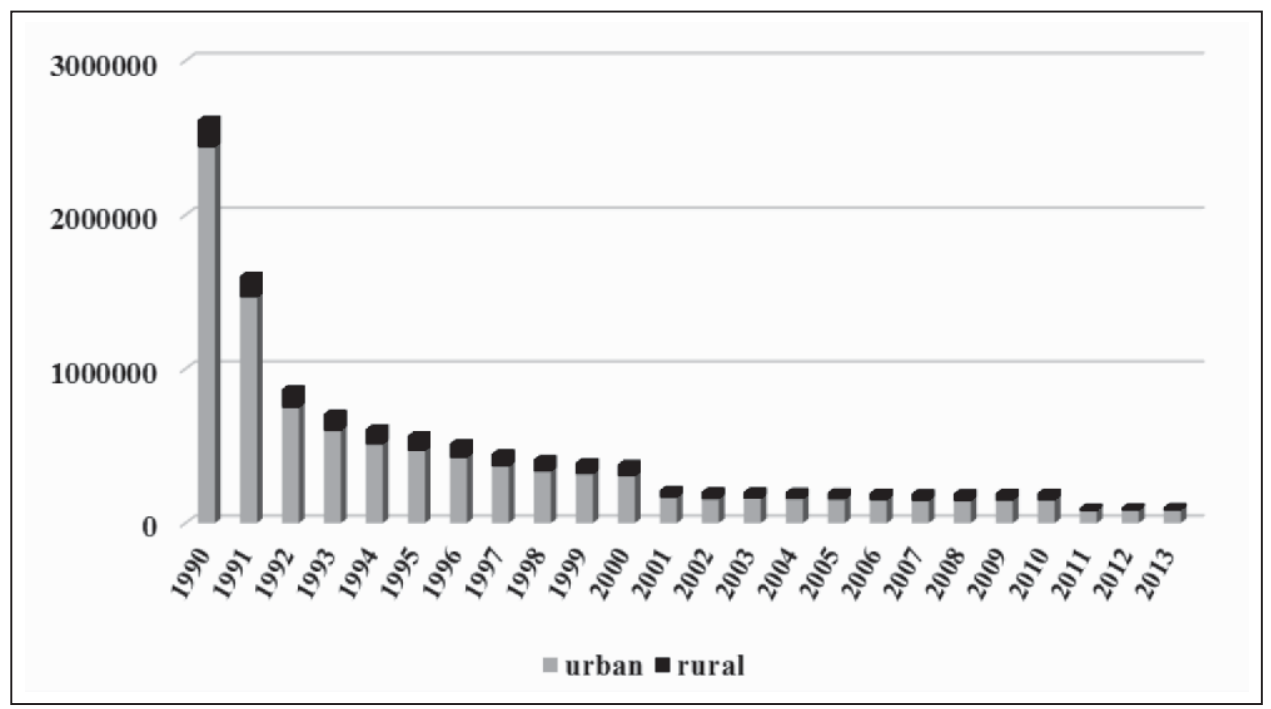

Figure 6. Housing mainly owned by the state, on residence average in Romania, during the period 1990-2013

The decrease of public investments in the sector of housing construction and the laws favouring the privatization of existing stock provoked a big decline in housing from the urban environment of public ownership, from 2.440 .804 units in 1990 (about $31 \%$ ) to 83.986 units $(2,12 \%$ ) (Figure 6). In the rural environment, in the context of decreased public investment in social housing, the alterations regarding ownership structures of housing were insignificant.

\section{Some final general remarks regarding the characteristics of housing stock from Romania}

The limits of territorial statistics regarding housing during the period 1950-2015 do not allow us some detailed thematic analyses for an initial period. generally, for examined period, the number of housing buildings and the housing had a significant increase. The general development of housing stock was connected during communist period to increase of population. During the post-communist period, against the background of liberalization of real estate markets and the freedom of internal and international mobility, the controlled connecting of dynamics of the housing stock was substituted by ultra-liberal policies for encouraging private investments in housing constructions. Thus, after 1990 even if the population of Romania decreased $(-16 \%)$, the number of housing increased $(+10 \%)$.

The urban environment, a beneficiary of most investments in the field of housing, but also of great urban transformations and implicitly residential ones, had an increase in the housing of over 150\% during the period 1966-2011, comparing to $9,09 \%$ in rural environment. If in 1966 the share of housing in the urban environment was of $34,04 \%$, respectively $65,96 \%$ in the urban environment, 


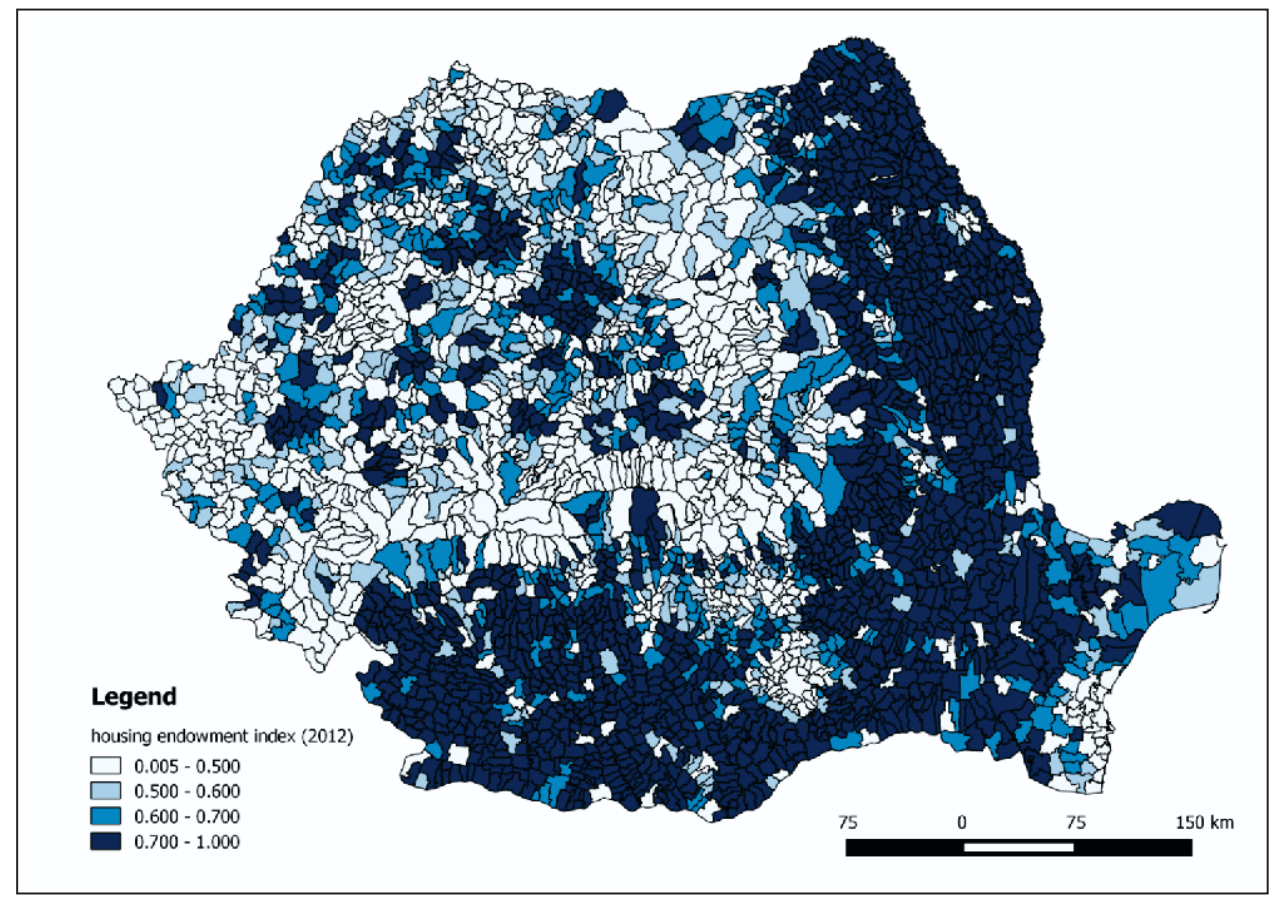

Figure 7. Housing Endowment Index in Romania (2012)

5 decades later, in 2011, these shares will be approximately inverted, being of $54,62 \%$ in the urban environment and respectively of $46,03 \%$ in the rural environment. The increase of $29,12 \%$ during the 4 period $1966-2011$ of the number of urban residential buildings, comparing to $10,41 \%$ in the rural environment, completes the general frame of constructive types (blocks of flats) and of big social and economic transformations modelled by systematization. We are mentioning that the change of residential practices and the flows of urban-rural migrations determined the numeric and the share decrease of urban population during the post-communist period (2,33 million inhabitants between 1992 and 2011). In this context, the proportion of the rural population increased, even if its number decreased. The significant alterations are connected to demographic and constructive dynamics from peri-urban, rural territories.

At the national level, against the background of the transformation of structure and characteristics of housing stock, and also of a general improvement of living conditions, housing endowment index shows the existence of significant local territorial disparities (Figure 7). Thus, a large area from east and south regions of Romania, excepting metropolitan area of Bucharest and significant urban crowd (Constanţa and the seaside, Iaşi, Ploieşti, Craiova, Bacău, Galaţi etc.) has high values of housing endowment index, proving the statistic remoteness of these areas from environments of indicators characterizing the living quality.

In the main ultra-liberal context of managing public services promoted by all right or left wing governments from post-communist Romania, the absence of coherent and consistent policies in the field of urban living and development 
favoured the increase of disparities between living in urban environment and in rural one (where new peri-urban living forms have their dysfunctions), between pavilion living and collective living, respectively between the forms of managing and exploiting public housing (a reduced, damaged stock, without extension perspectives) and the private ones (from which there is a lot of secondary housing or housing for rent in a free market not regulated).

\section{Acknowledgements}

The paper received a financial support through the project "SOCERT. Society of knowledge, dynamism by research", contract identification number POSDRU/159/1.5/S/132406. The project is co-financed by European Social Fund through Sectorial Operational Programme Development of Human Resources 2007-2013. Invest in people!”

\section{References}

Baross, P \& Struyk, R 1993, 'Housing transition in Eastern Europe. Progress and problems', Cities, vol. 10, no. 3, pp. 179-188.

Bengt, T \& Tsenkova, S 2004, 'The future of social housing in Eastern Europe> reforms in Latvia and Ukraine', International Journal of Housing Policy, vol. 4, no. 2, pp. 133-149.

Council of Ministers 1968, Decision no. 1651/1968 for applying the provisions of Law no. $10 / 1968$ regarding the management of housing stock and regulation of relations between owners and tenants, Official Gazette no. 114/31.07.1968.

Council of Ministers 1968, Decision no. 1735/1968 for applying the provisions of Law no. 9/1968 regarding the development of housing construction, sale of housing from state stock to population and construction of real estate for leisure or tourist, Official Gazette no. 104/31.071968.

Dumistracel, S 1995, Disappeared villages - threatened villages, European Institute, Iasi

Grand National Assembly 1952, Decree no. 142/1952 for delaring some localities from Snagov district, Bucharest region, as "resorts for working class", Official Gazette no. 33/28.06.1952.

Grand National Assembly 1974, Law no. 58/1974 on land use and and urban and rural localities planning, Official Gazette no. 135/01.11.1974.

Hegedüs, J 2009, A Review of 'The Post-Socialist City: Urban Form and Space Transformation in Central and Eastern Europe after Socialism', European Journal of Housing Policy, vol. 9, no. 1, pp. 98-102.

Herfert, G, Neugbauer, SC \& Smigiel, C 2013, 'Living in residential satisfaction? Insights from large-scale housing estates in Central and Eastern Europe', Journal of Economic and Social Geography, vol. 104, no. 1, pp. 57-74.

Lazarescu, C 1982, 'A priority field of our work - The housing', Arhitectur(

Lux, M 2003, 'Efficiency and effectiveness of housing policies in the Central and Eastern Europe Countries', International Journal of Housing Policy, vol. 3, no. 3, pp. 243-265.

Lux, M \& Sunega, P 2014, 'Public Housing in the Post-Socialist States of Central and Eastern 
Europe: Decline and an Open Future', Housing Studies, vol. 29, no. 4, pp. 501-519.

Ministry of Regional Development and Public Administration 2013, Public works, viewed 12 september 2014, www.mdrap.ro/lucrari-publice/-1763

Morton, HW 1979, 'Housing Problems and Policies of Eastern Europe and the Soviet Union', Studies in Comparative Communism, 12, 4, p. 300-321.

National Housing Agency 2015, Programs, viewed 12 september 2015 , www.anl.ro/ro/programe/

National Institute of Statistics 2015, Population census from 1948, 1956, 1966, 1977, 1992, 2001, 2011, Bucharest.

Noica, N 2003, Intre istorie şi actualitate. Politici de locuire în România, Masina de scris, Bucharest.

Pichler-Milanovich, N 2001, 'Urban housing markets in Central and Eastern Europe: convergence, divergence or policy „,collapse”', International Journal of Housing Policy, vol. 1, no. 2, pp. 145-187.

State Council 1981, Decree no. 216/1981 regarding the modification of some regulations for determining limit prices for housing to be erected from state funds, contracting prices of real estate and sale prices of housing from state housing stock, Official Gazette no. $57 / 06.08 .1981$.

Suditu, B 2009, 'Urban sprawl and residential mobilities in the Bucharest area reconfiguration of a new residential geography', Human Geographies - Journal of Studies and Research in Human Geography, vol. 4, no. 2, pp. 79-93

Suditu, B 2012, 'Urban Sprawl - The Legal Context And Territorial Practices In Romania', Human Geographies - Journal of Studies and Research in Human Geography, vol. 6, no. 1, pp. 7377

Tanase, S 1998, Elites and society. Governing of Gh. Gheorghiu Dej 1945-1965, Humanitas, Bucureşti.

Vâlceanu, DG, Suditu, B, Toth, G \& Ivana, C 2015, 'Housing inequalities regarding the informal settlements in Romania', Romanian Review of Regional Studies, vol. 11, no. 1, pp. 89-100. 